\title{
Some Reflections on Foreign Direct Investment Flows and the Viet Nam's Economy
}

\author{
Abdullah Kaid Al-Swidi (Corresponding author) \\ School of Quantitative Science, College of Arts and Sciences, University Utara Malaysia \\ Tel: 00-601-2466-2754Ｅ-mail: swidi@uum.edu.my
}

Arfan Shahzad

Othman Yeop Abdullah Graduate School of Business, University Utara Malaysia

Dawood Ali M. Mithani

Othman Yeop Abdullah Graduate School of Business, University Utara Malaysia

Faudziah Hanim Bt Fadzil

Othman Yeop Abdullah Graduate School of Business, University Utara Malaysia

Abd Ghani B Golamdin

School of Computing, College of Arts and Sciences, University Utara Malaysia

Received: October 23, 2012 Accepted: November 8, 2012

doi:10.5296/ber.v2i2.2551 URL: http://dx.doi.org/10.5296/ber.v2i2.2551

\begin{abstract}
This paper examined the comparative trend and pattern of foreign direct investment (FDI) flows in Vietnam over the period (2001-2011) in the ASEAN setting. Astonishingly, the period study has detected a declining trend of FDI inflows in Vietnam at the end of the preceding decade and being of the current decade. Together with the Vietnamese other parameters, the business environment is, thus, analyzed for a better perception and galvanizing ideas for policy diagnosis in the future course of direction of the FDI into the country. Moreover, for a better regional contribution, a formation of VCLT-DS (Vietnam,
\end{abstract}


Cambodia, Laos, Thailand, and Development Square) similar to the IMT-GT (Indonesia, Malaysia, Thailand Growth Triangle) is suggested for the consideration of the concerned political authorities.

Keywords: Foreign Direct Investment, ASEAN, Viet Nam, Transnationality, Performance Index, Potential Index.

\section{Introduction}

According to the IMF's Balance of Payments Manual ( $5^{\text {th }}$ edition), foreign direct investment (FDI) refers to the kind of "international investment that reflects the objective of a resident in one economy (the direct investor) obtaining a lasting interest in an enterprise resident in another economy (the direct investment, enterprise). The interest implies the existence of a long-term relationship between the direct investor and the direct investment enterprise, and a significant degree of finance by the investor and management of the enterprise" (IMF, 2003, p.6). The FDI comprises initial as well as all subsequent capital transactions between the two involved parties - investors and enterprise - of the different countries. The FDI inflows are largely comprised by the equity capital. Besides, trade credits, loans and advances are also the components of the FDI. Its significance is attributed to the fact that in a host country, particularly business firms which receive the investment, it provides a source of new technologies, additional business capital, processes, product development, organizational methods, new marketing, and management skills. It can provide a strong impetus for business growth and economic development.

The FDI flows are referred to in two categories: inflows and outflows. The FDI inflows are the net inward FDI transactions (inward investments minus disinvestments) in the reporting country. The FDI outflows are the net outward FDI transactions (outward investments minus disinvestments) made abroad by the reporting economy.

From 1992s onwards, due to a high degree of interaction of international capital markets, there has been a substantial growth of the FDI flows world over. The average growth rate of global FDI inflows during the period 2001-2011 was 124\%, and 209\% for the ASEAN region. For details, refer to the data in Table 1.

In the Asia-Pacific belt among the ASEAN countries, however, Viet Nam has emerged as a promising nation acquiring a unique position of rapidly growing newly industrialized open economy in the past two decades. Viet Nam being in the midst of business and economic cluster of the South-East Asia, it is worthwhile to examine its growth characteristics in the light of FDI flows in its development process, performance, and prospects. In fact, during the last decade, 2011, the FDI inflows have increased six fold from 1300 million US Dollar in 2001 to 800 million US dollars in 2010. It, however, declined 7 per cent to 7430 million US Dollar in 2011. 


\section{Al Macrothink}

Business and Economic Research

ISSN 2162-4860

2012, Vol. 2, No. 2

Table 1. Regional Allocation of FDI Inflows, 2001 - 2011(Billions of U.S. dollars)

\begin{tabular}{|c|c|c|c|c|c|c|c|c|c|c|c|}
\hline & 2001 & 2002 & 2003 & 2004 & 2005 & 2006 & 2007 & 2008 & 2009 & 2010 & 2011 \\
\hline World & 817,574 & 716,128 & 559,576 & 710,755 & 958,697 & $1,411,018$ & $1,833,324$ & $1,790,706$ & $1,197,824$ & $1,309,001$ & $1,524,422$ \\
\hline $\begin{array}{l}\text { Developed } \\
\text { countries }\end{array}$ & 571,483 & 547,778 & 366,573 & 396,145 & 611,283 & 940,861 & $1,247,635$ & $1,056,594.6$ & $669,788.1$ & $732,324.8$ & $870,662.2$ \\
\hline $\begin{array}{l}\text { Developing } \\
\text { Countries }\end{array}$ & 219,721 & 155,528 & 172,033 & 275,032 & 316,444 & $433,017.4$ & $605,164.7$ & $731,249.9$ & $525,704.9$ & $574,325.3$ & $651,838.8$ \\
\hline Asia & 111,966 & 92,009 & 107,278 & 156,622 & 210,572 & $224,483.5$ & $302,139.5$ & $331,120.1$ & $279,777.3$ & $340,642.5$ & $390,305.3$ \\
\hline ASEAN & 19,601 & 14,507 & 17,364 & 25,666 & 39,091 & 51,243 & 60,514 & $50,214.0$ & $47,357.8$ & $92,733.0$ & $116,539.2$ \\
\hline Viet Nam & 1,300 & 1,200 & 1,450 & 1,610 & 2,021 & 2,360 & 6,739 & $9,579.0$ & $7,600.0$ & $8,000.0$ & $7,430.0$ \\
\hline
\end{tabular}

Sources: UNCTAD, World Investment Reports, 2011.

Although many studies are available on the FDI flows in the literature, there are new emerging growing economies in the ASEAN region need to be studied as case studies to explore the trends of the flow of the global FDI. The present case study about Viet Nam is a humble attempt to narrate some comparative observations and empirical analysis of the facts and the prospects of Viet Nam in the gamut of FDI flows in the ASEAN region as well as in the global setting. The study is largely confined to reviewing the trends and pattern of FDI inflows and outflows, briefly examining the major economic and policy issues pertaining to Viet Nam. The study is data-based, analytical and comparative in nature at the macro level. It is interacted to draw some lessons for the benefit of policy makers in the region and other developing economies in the contemporary era.

\section{Economic Scenario of the Vietnamese Economy in the ASEAN Context}

The economy of Viet Nam has become one of the fastest growing economies led by Doi Moi Economic Reforms and Renovation plan 1986 in the country. Besides, FDI flows in Viet Nam have been one of the most significant factors that ensured a rapid and sustainable growth and also quite successful in the eradication of poverty. Over the years, FDI played an important role in Viet Nam's economic integration at the regional and global levels. Under the WTO accession, Viet Nam witnessed the liberalization of FDI entry in the service sector and this in turn improved further the investment environment of the country. In the years to follow, the FDI inflow is expected to increase in Viet Nam as the nation is becoming one of the top destinations of FDI (World Investment Report, 2008). Data in table 2, relates to the propensity to export and import of Viet Nam during the period 2001-2011. 
Table 2. Viet Nam's Trade Flows 2001- 2011

\begin{tabular}{|c|c|c|c|c|c|c|c|c|c|c|c|}
\hline & 2001 & 2002 & 2003 & 2004 & 2005 & 2006 & 2007 & 2008 & 2009 & 2010 & 2011 \\
\hline GDP & $32,685.2$ & $35,064.1$ & $39,552.50$ & $45,427.90$ & $52,917.40$ & $60,913.30$ & $71,076.70$ & $89,185.20$ & $80,901.2$ & $96,634.7$ & $123,664.9$ \\
\hline $\operatorname{Exp}(X)$ & $15,029.2$ & $16,706.1$ & $20,149.30$ & $26,485.00$ & $32,442.00$ & $39,605.00$ & $48,302.00$ & $60,938.00$ & $56,543.0$ & $71,970.0$ & $95,222.0$ \\
\hline $\operatorname{Imp}(M)$ & $16,217.9$ & $19,745.6$ & $25,255.80$ & $31,968.80$ & $36,978.00$ & $44,410.00$ & $60,869.00$ & $79,293.00$ & $68,922.0$ & $83,970.0$ & $104,524.0$ \\
\hline $\begin{array}{c}\text { Growth } \\
\text { Rate (\%) }\end{array}$ & 6.9 & 7.1 & 7.3 & 7.8 & 8.4 & 8.2 & 8.5 & 6.3 & 5.4 & 6.9 & 5.9 \\
\hline $\begin{array}{c}\text { Trade } \\
\text { Intensity } \\
(\%)\end{array}$ & 96 & 103 & 114.8 & 128.7 & 131.2 & 137.9 & 153.6 & 157.2 & 157.24 & 161.37 & 161.52 \\
\hline $\begin{array}{l}\text { Propensity } \\
\text { to Export } \\
\text { (PX) (\%) }\end{array}$ & 45.98 & 47.64 & 50.9 & 58.3 & 61.3 & 65.0 & 68.0 & 68.3 & 69.89 & 74.48 & 77.00 \\
\hline $\begin{array}{c}\text { Propensity } \\
\text { to Import } \\
\text { (PM) (\%) }\end{array}$ & 49.62 & 56.31 & 63.9 & 70.4 & 69.9 & 72.9 & 85.6 & 88.9 & 85.19 & 86.89 & 84.52 \\
\hline
\end{tabular}

Note:

Trade Intensity $=[(\mathrm{X}+\mathrm{M}) / \mathrm{GDP}] 100$

$\mathrm{PX}=(\mathrm{X} / \mathrm{GDP}) * 100 \mathrm{PM}=(\mathrm{M} / \mathrm{GDP}) * 100$

Source: UNCTAD, 2011

Data in Table 2 reveals that in recent years, Viet Nam economy's degree of openness is continuously increasing, since the trade intensity has increased from $96.0 \%$ in 2001 to $161.52 \%$ in 2011: Likewise, the country's export and import propensities also depict a rising trend. A policy caution, however, is needed for the country's imports are exceeding the exports the gap is widening and causing rising current account deficits (CAD). A cumulative CAD in the future may adversely affect the country's balance of payments and its exchange rate.

\section{Economic Growth Rate}

Data in Table 3 refer to the economic growth rate for the ASEAN 10.It is observed that Viet Nam has an average growth rate of $7.75 \%$ which comes third after Myanmar and Cambodia in the ASEAN 10 region. 


\section{Macrothink}

Table 3. The growth rate (\%) of Viet Nam and ASEAN 10 countries

\begin{tabular}{|l|l|l|l|l|l|l|l|l|l|l|l|}
\hline Country/Year & $\mathbf{2 0 0 1}$ & $\mathbf{2 0 0 2}$ & $\mathbf{2 0 0 3}$ & $\mathbf{2 0 0 4}$ & $\mathbf{2 0 0 5}$ & $\mathbf{2 0 0 6}$ & $\mathbf{2 0 0 7}$ & $\mathbf{2 0 0 8}$ & $\mathbf{2 0 0 9}$ & $\mathbf{2 0 1 0}$ & $\mathbf{2 0 1 1}$ \\
\hline Brunei & 2.7 & 3.9 & 2.90 & 0.50 & 0.40 & 4.40 & 0.60 & -1.9 & -1.8 & 2.6 & 1.9 \\
\hline Cambodia & 8.1 & 6.6 & 8.50 & 10.30 & 13.30 & 10.80 & 10.20 & 6.7 & 0.1 & 6.0 & 6.1 \\
\hline Indonesia & 3.6 & 4.5 & 4.80 & 5.00 & 5.70 & 5.50 & 6.30 & 6.0 & 4.6 & 6.2 & 6.5 \\
\hline Laos & 4.6 & 6.9 & 6.10 & 6.40 & 7.10 & 8.10 & 7.90 & 7.8 & 7.6 & 7.9 & 8.3 \\
\hline Malaysia & 0.5 & 6.4 & 5.80 & 6.80 & 5.30 & 5.6 & 6.3 & 4.8 & -1.5 & 7.2 & 5.1 \\
\hline Myanmar & 11.3 & 12.0 & 13.80 & 13.60 & 13.60 & 12.70 & 5.50 & 3.6 & 5.1 & 5.3 & 5.5 \\
\hline Philippines & 2.9 & 3.6 & 4.90 & 6.40 & 5.00 & 5.40 & 7.20 & 3.6 & 5.1 & 5.3 & 5.5 \\
\hline Singapore & -1.2 & 4.2 & 3.50 & 9.00 & 7.30 & 8.20 & 7.70 & 1.7 & -1.0 & 14.8 & 4.9 \\
\hline Thailand & 2.2 & 5.3 & 7.10 & 6.30 & 4.50 & 5.10 & 4.80 & 2.5 & -2.3 & 7.8 & 0.1 \\
\hline Vietnam & 6.9 & 7.1 & 7.30 & 7.80 & 8.40 & 8.20 & 8.50 & 6.1 & 5.4 & 6.9 & 5.9 \\
\hline
\end{tabular}

Source: UNCTAD, 2011 Real GDP Growth: Euromonitor International from national statistics/Eurostat/OECD/UN/International Monetary Fund (IMF)

The Data in Table 4 is related to the Trade Intensity Indices (TII) of the ASEAN countries. The Trade Intensity Index is measured in percentage terms as the ratio of trade (X+M) to GDP. TII is the indicate of the degree of openness of the country. A reading through the Table 4 indicates that over the years these have been a rising trend of trade intensity of Viet Nam. As such by Viet Nam $(161 \%)$ is ranked second in the degree of openness, next to Singapore (298\%). Incidentally, it has supposed Malaysia (186\%) in 2006 to 149 in 2011.

Table 4. The Trade Intensity of Viet Nam and ASEAN 10 (2001-2011)

\begin{tabular}{|c|r|r|c|c|c|c|c|c|c|c|c|}
\hline Country/Year & 2001 & 2002 & 2003 & 2004 & 2005 & 2006 & 2007 & 2008 & 2009 & 2010 & 2011 \\
\hline Brunei & $83 \%$ & $87 \%$ & $80 \%$ & $70 \%$ & $60 \%$ & $51 \%$ & $50 \%$ & $70 \%$ & $84 \%$ & $87 \%$ & $100 \%$ \\
\hline Cambodia & $90 \%$ & $99 \%$ & $100 \%$ & $113 \%$ & $113 \%$ & $118 \%$ & $112 \%$ & $97 \%$ & $96 \%$ & $106 \%$ & $127 \%$ \\
\hline Indonesia & $54 \%$ & $45 \%$ & $45 \%$ & $49 \%$ & $57 \%$ & $50 \%$ & $49 \%$ & $53 \%$ & $40 \%$ & $41 \%$ & $45 \%$ \\
\hline Laos & $50 \%$ & $43 \%$ & $37 \%$ & $43 \%$ & $50 \%$ & $56 \%$ & $47 \%$ & $42 \%$ & $45 \%$ & $59 \%$ & $64 \%$ \\
\hline Malaysia & $174 \%$ & $172 \%$ & $165 \%$ & $185 \%$ & $185 \%$ & $186 \%$ & $173 \%$ & $179 \%$ & $146 \%$ & $153 \%$ & $149 \%$ \\
\hline Myanmar & $80 \%$ & $79 \%$ & $44 \%$ & $42 \%$ & $47 \%$ & $54 \%$ & $71 \%$ & $75 \%$ & $30 \%$ & $28 \%$ & $35 \%$ \\
\hline Philippines & $88 \%$ & $89 \%$ & $95 \%$ & $94 \%$ & $88 \%$ & $86 \%$ & $75 \%$ & $67 \%$ & $50 \%$ & $55 \%$ & $50 \%$ \\
\hline Singapore & $271 \%$ & $267 \%$ & $292 \%$ & $332 \%$ & $359 \%$ & $374 \%$ & $349 \%$ & $373 \%$ & $281 \%$ & $291 \%$ & $298 \%$ \\
\hline Thailand & $102 \%$ & $97 \%$ & $109 \%$ & $118 \%$ & $129 \%$ & $126 \%$ & $120 \%$ & $132 \%$ & $102 \%$ & $112 \%$ & $124 \%$ \\
\hline Vietnam & $96 \%$ & $104 \%$ & $115 \%$ & $129 \%$ & $131 \%$ & $138 \%$ & $154 \%$ & $157 \%$ & $157 \%$ & $161 \%$ & $161 \%$ \\
\hline ASEAN 10 & $109 \%$ & $108 \%$ & $120 \%$ & $131 \%$ & $135 \%$ & $138 \%$ & $133 \%$ & $138 \%$ & $115 \%$ & $121 \%$ & $128 \%$ \\
\hline
\end{tabular}

Source: UNCTAD, 2011

\section{FDI Inflows in the Globe, the ASEAN, and Viet Nam}

Over the years, there has been a substantial change in the inflows of foreign direct investment, in its growth trends and diversification across the world economy and the ASEAN cluster. What is remarkable is the phenomenal growth of FDI inflows during 2001-2011. 


\section{MInstitute Macrothink}

Business and Economic Research ISSN 2162-4860 2012, Vol. 2, No. 2

Data in Table 5 reveals that the FDI inflow in the globe has tripled from 824,445 million US dollars in 2001 to $1,524,422$ million US dollars in 2011. A country's gross FDI inflows at the end of the total period are the total amount of direct investments received from non-resident investors during the period of time. Over the years, the rise in FDI flows was due to increased cross-border mergers and acquisitions in the banking industry, extraction and related service industries, as well as Greenfield investments. UNCTAD estimated that global FDI inflows in 2007 reached a new high of USD 1,833,324 million (2006: USD 1,411,018 million). This implies that FDI flows remain unaffected by the turmoil in the financial markets. In 2007, world FDI inflows have doubled from what they were in 2005.

Incidentally, in the case of ASEAN the FDI inflows has increased three fold from 20,781 million US dollars in 2001 to $(116,539.20)$ million US dollars in 2011 , despite the early set-back due to the 1997- Asian financial crisis in the region. In the same way, the FDI inflows to Viet Nam have significantly increased from 1,289 million US dollars (which constitutes $5.5 \%$ of FDI inflows to ASEAN in 2000) to 6,739 million US dollars which constitutes $11.1 \%$ of the FDI share in total flows accrued to the ASEAN countries. Refer to data in Table 5 for more details.

Table 5. FDI Inflows in World, ASEAN countries including Viet Nam 2001-2011; (US\$ Millions)

\begin{tabular}{|r|r|r|r|r|r|}
\hline \multirow{2}{*}{ Year } & \multirow{2}{*}{ World } & \multirow{2}{*}{ ASEAN } & \multirow{2}{*}{ Viet Nam } & ASEAN/ & Viet Nam/ \\
\cline { 5 - 6 } & & & & World & ASEAN \\
\hline 2001 & 824,445 & 20,781 & 1,300 & $2.5 \%$ & $6.3 \%$ \\
\hline 2002 & 625,168 & 18,111 & 1,200 & $2.9 \%$ & $6.6 \%$ \\
\hline 2003 & 561,056 & 24,581 & 1,450 & $4.4 \%$ & $5.9 \%$ \\
\hline 2004 & 717,695 & 35,245 & 1,610 & $4.9 \%$ & $4.6 \%$ \\
\hline 2005 & 958,697 & 39,091 & 2,021 & $4.1 \%$ & $5.2 \%$ \\
\hline 2006 & $1,411,018$ & 51,243 & 2,360 & $3.6 \%$ & $4.6 \%$ \\
\hline 2007 & $1,833,324$ & 60,514 & 6,739 & $3.3 \%$ & $11.1 \%$ \\
\hline 2008 & $1,790,706$ & $50,214.00$ & 9,579 & $2.80 \%$ & $19.08 \%$ \\
\hline 2009 & $1,197,824$ & $47,357.80$ & 7,600 & $3.95 \%$ & $16.05 \%$ \\
\hline 2010 & $1,309,001$ & $92,733.00$ & 8,000 & $7.08 \%$ & $8.63 \%$ \\
\hline 2011 & $1,524,422$ & $116,539.20$ & 7,430 & $7.64 \%$ & $6.38 \%$ \\
\hline
\end{tabular}

Source: UNCTAD, World Investment Report, 2011 


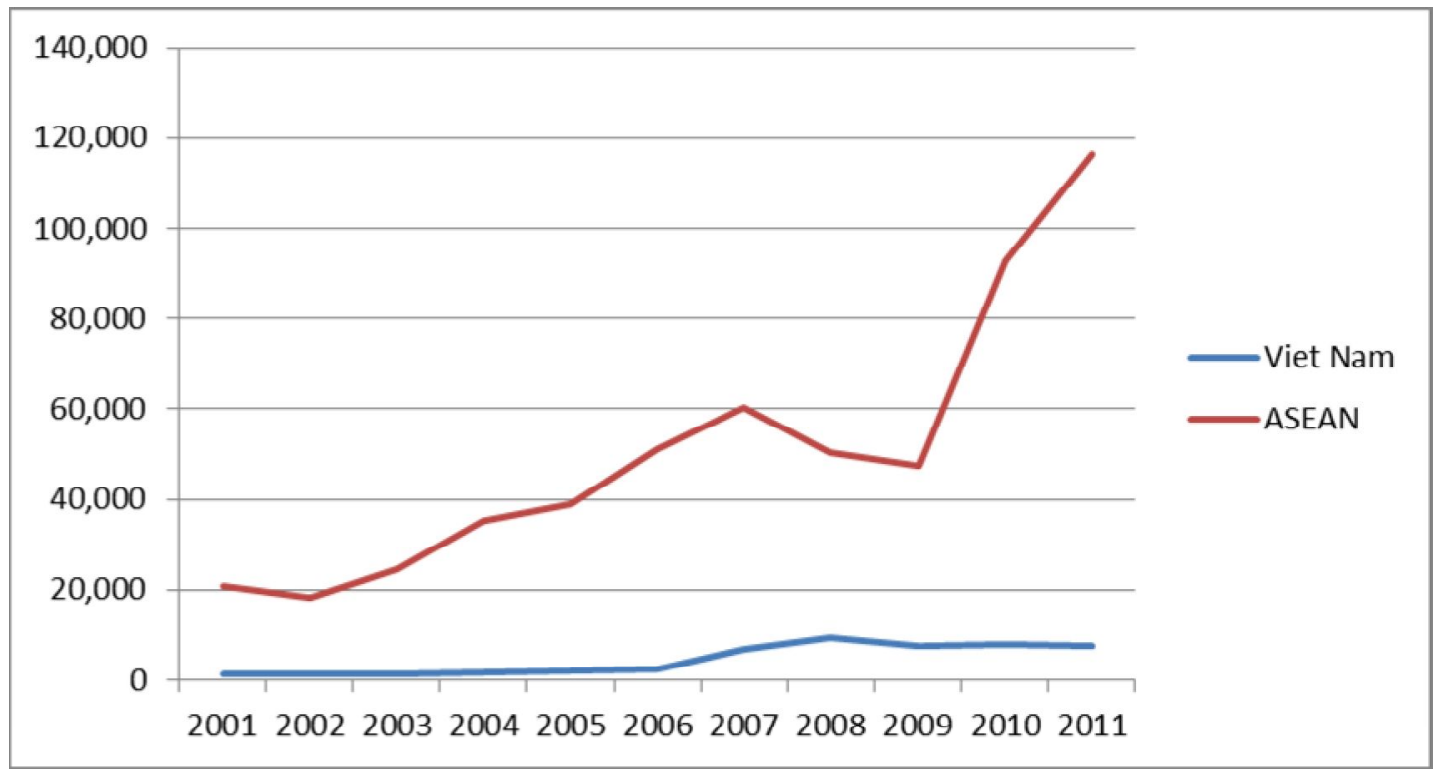

Figure 1. The FDI inflow in ASEAN and Vietnam during the period 2001-2011

Figure 1 denotes the trend behaviour of the FDI inflows in Viet Nam compared with the ASEAN during the period 2001 - 2011.

Data in Table 5 are related to the FDI inflows in selected ASEAN countries namely Indonesia, Malaysia, Philippines, Viet Nam, and Thailand. Data table 5 reflects that the FDI inflows have steadily grown in these economies, in the recent years. Starting from the year, 2001 onwards Indonesia, Malaysia, Philippines, Thailand, and Vietnam have increasing trend of FDI except a significant decrease between the years 2005-2006 in case of Indonesia. Furthermore, in the ASEAN region Thailand is becoming the most attractive destination of FDI inflows over the whole period of comparison, and Malaysia comes next. However, Vietnam witnessed a slow increase starting from 2000 until 2005 but sharp and dramatic increase is seen 2005 onwards. Figure 2 provides a visual effect of the comparative trend behaviour of FDI in these five selected ASEAN nations.

Table 5. Relative shares of the ASEAN Countries including Vietnam in FDI inflows (2001-2011)

\begin{tabular}{|c|c|c|c|c|c|c|c|c|c|c|c|}
\hline & & & & Viet Nam/ & Viet Nam/ & & Indonesia/ & Indonesia/ & & Malaysia/ & Malaysia/ \\
\hline Year & World & ASEAN & Viet Nam & ASEAN & World & Indonesia & ASEAN & World & Malaysia & ASEAN & World \\
\hline 2001 & 817,574 & 20,781 & 1,300 & $6.30 \%$ & $0.20 \%$ & $-2,926$ & $-14.10 \%$ & $-0.40 \%$ & 554 & $2.70 \%$ & $0.10 \%$ \\
\hline 2002 & 716,128 & 18,111 & 1,200 & $6.60 \%$ & $0.20 \%$ & 232 & $1.30 \%$ & $0.00 \%$ & 3,203 & $17.70 \%$ & $0.40 \%$ \\
\hline 2003 & 557,869 & 24,581 & 1,450 & $5.90 \%$ & $0.30 \%$ & -507 & $-2.10 \%$ & $-0.10 \%$ & 2,473 & $10.10 \%$ & $0.40 \%$ \\
\hline 2004 & 742,143 & 35,245 & 1,610 & $4.60 \%$ & $0.20 \%$ & 1,896 & $5.40 \%$ & $0.30 \%$ & 4,624 & $13.10 \%$ & $0.60 \%$ \\
\hline 2005 & 958,697 & 39,091 & 2,021 & $5.20 \%$ & $0.20 \%$ & 8,337 & $21.30 \%$ & $0.90 \%$ & 3,967 & $10.10 \%$ & $0.40 \%$ \\
\hline 2006 & $1,411,018$ & 51,243 & 2,360 & $4.60 \%$ & $0.20 \%$ & 4,914 & $9.60 \%$ & $0.30 \%$ & 6,048 & $11.80 \%$ & $0.40 \%$ \\
\hline 2007 & $1,833,324$ & 60,514 & 6,739 & $11.10 \%$ & $0.40 \%$ & 6,928 & $11.40 \%$ & $0.40 \%$ & 8,403 & $13.90 \%$ & $0.50 \%$ \\
\hline 2008 & $1,790,706$ & $50,214.00$ & 9,579 & 19.08 & 0.53 & 9,318 & 18.56 & 0.52 & $7,172.00$ & 14.28 & 0.40 \\
\hline
\end{tabular}




\section{Macrothink}

Business and Economic Research

ISSN 2162-4860

2012, Vol. 2, No. 2

\begin{tabular}{|c|c|c|c|c|c|c|c|c|c|c|c|}
\hline 2009 & $1,197,824$ & $47,357.80$ & 7,600 & 16.05 & 0.63 & 4,877 & 10.30 & 0.41 & $1,453.00$ & 3.07 & 0.12 \\
\hline 2010 & $1,309,001$ & $92,733.00$ & 8,000 & 8.63 & 0.61 & 13,771 & 14.85 & 1.05 & $9,103.00$ & 9.82 & 0.70 \\
\hline 2011 & $1,524,422$ & $116,539.20$ & 7,430 & 6.38 & 0.49 & 18,906 & 16.22 & 1.24 & $11,966.00$ & 10.27 & 0.78 \\
\hline \multirow[b]{2}{*}{ Year } & \multirow[b]{2}{*}{ World } & \multirow[b]{2}{*}{ ASEAN } & \multirow[b]{2}{*}{ Philippines } & Philippines/ & Philippines/ & \multirow[b]{2}{*}{ Thailand } & Thailand/ & Thailand/ & & & \\
\hline & & & & ASEAN & World & & ASEAN & World & & & \\
\hline 2001 & 817,574 & 20,781 & 195 & $0.90 \%$ & $0.00 \%$ & 5,061 & $24.40 \%$ & $0.60 \%$ & & & \\
\hline 2002 & 716,128 & 18,111 & 1,542 & $8.50 \%$ & $0.20 \%$ & 3,335 & $18.40 \%$ & $0.50 \%$ & & & \\
\hline 2003 & 557,869 & 24,581 & 491 & $2.00 \%$ & $0.10 \%$ & 5,235 & $21.30 \%$ & $0.90 \%$ & & & \\
\hline 2004 & 742,143 & 35,245 & 688 & $2.00 \%$ & $0.10 \%$ & 5,862 & $16.60 \%$ & $0.80 \%$ & & & \\
\hline 2005 & 958,697 & 39,091 & 1,854 & $4.70 \%$ & $0.20 \%$ & 8,048 & $20.60 \%$ & $0.80 \%$ & & & \\
\hline 2006 & $1,411,018$ & 51,243 & 2,921 & $5.70 \%$ & $0.20 \%$ & 9,010 & $17.60 \%$ & $0.60 \%$ & & & \\
\hline 2007 & $1,833,324$ & 60,514 & 2,928 & $4.80 \%$ & $0.20 \%$ & 9,575 & $15.80 \%$ & $0.50 \%$ & & & \\
\hline 2008 & $1,790,706$ & $50,214.00$ & $1,544.0$ & 3.07 & 0.09 & $8,454.70$ & 16.84 & 0.47 & & & \\
\hline 2009 & $1,197,824$ & $47,357.80$ & $1,963.00$ & 4.15 & 0.16 & $4,854.40$ & 10.25 & 0.41 & & & \\
\hline 2010 & $1,309,001$ & $92,733.00$ & $1,298.00$ & 1.40 & 0.10 & $9,733.30$ & 10.50 & 0.74 & & & \\
\hline 2011 & $1,524,422$ & $116,539.20$ & $1,262.00$ & 1.08 & 0.08 & $9,572.00$ & 8.21 & 0.63 & & & \\
\hline
\end{tabular}

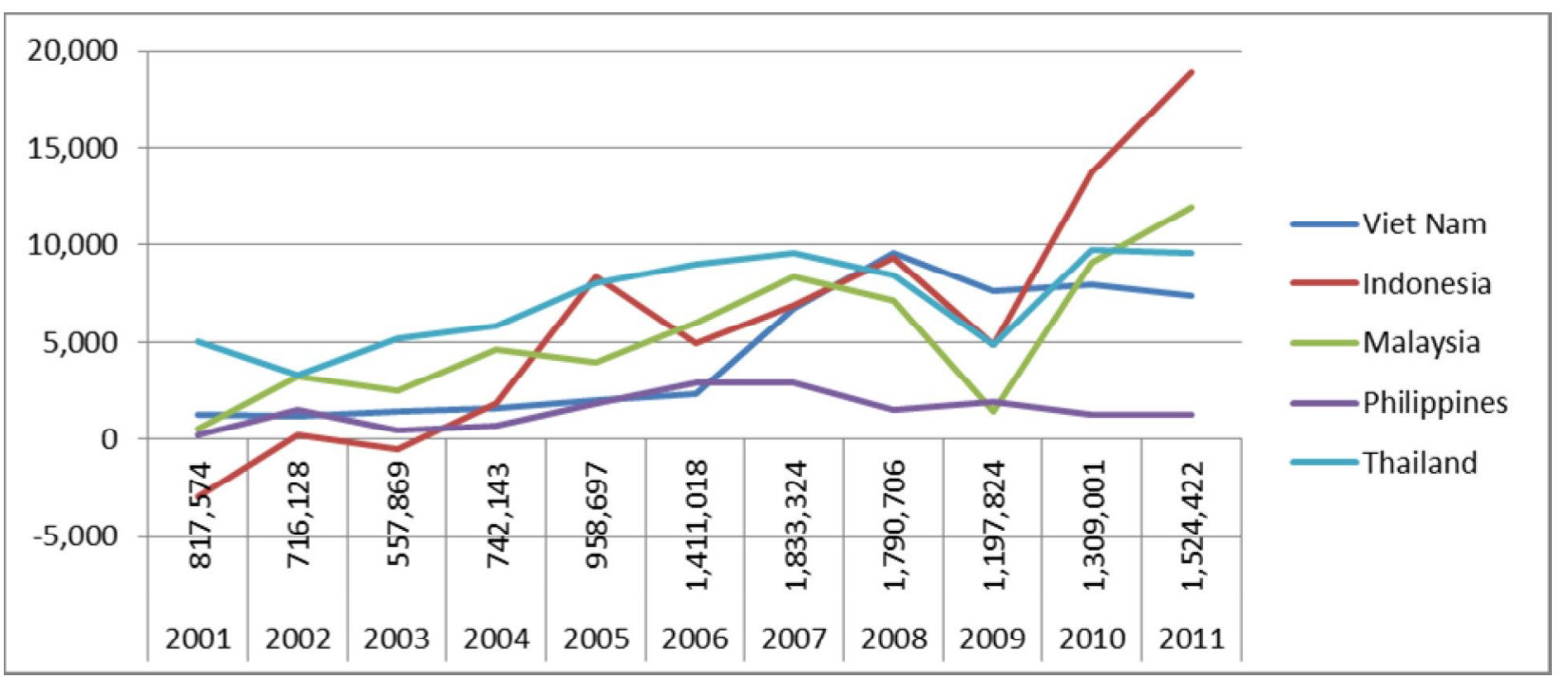

Figure 2. The growth of FDI inflows to some ASEAN selected countries 2001-2011

\section{FDI in Viet Nam by the Country of Origin}

Data in Table 6 relate to the FDI flows in Viet Nam by the Country of Origin.

Table 6. Foreign Direct Investment by country of origin 1988-2011(billion US)

\begin{tabular}{|l|l|l|l|l|}
\hline Country & Number of Projects & Share \% & Registered Capital & Share \% \\
\hline Taiwan & 2,227 & 16.39 & 23.60 & 11.76 \\
\hline Singapore & 1,016 & 7.48 & 23.00 & 11.47 \\
\hline
\end{tabular}




\begin{tabular}{|l|l|l|l|l|}
\hline Korea & 2,988 & 21.99 & 24.00 & 11.96 \\
\hline Japan & 1,596 & 11.75 & 26.16 & 13.04 \\
\hline Hong Kong & 662 & 4.87 & 15.60 & 7.78 \\
\hline British Virgin Island & 506 & 3.72 & 11.31 & 5.64 \\
\hline Netherland & 164 & 1.21 & 5.86 & 2.92 \\
\hline Cayman Islands & 53 & 0.39 & 7.50 & 3.74 \\
\hline US & 614 & 4.52 & 10.39 & 5.18 \\
\hline Malaysia & 404 & 2.97 & 11.09 & 5.53 \\
\hline Others & 3,358 & 24.71 & 42.77 & 21.32 \\
\hline Total & 13,588 & $100 \%$ & 200.76 & $100 \%$ \\
\hline
\end{tabular}

Source: FIA Vietnam, 2011

\section{Sector-Wise FDI Inflows}

Data in Table 7 refer to the sector-wise allocation of FDI inflows in Viet Nam, over the years. It follows that the manufacturing sector in the country has received increasingly a large share of the FDI. Though agriculture initially received a much smaller share (5\%) of FDI, its share has become nearly double in the new millennium era. Surprisingly, a substantial decline is noticed in the FDI inflows in the service sector of Viet Nam.

Table 7. Top 10 Foreign Direct Investment sectors in Vietnam (1988-3/2012)

\begin{tabular}{|l|l|l|c|}
\hline Sector & $\begin{array}{l}\text { No. } \\
\text { Project }\end{array}$ & $\begin{array}{l}\text { Registered capital (billion } \\
\text { USD) }\end{array}$ & $\%$ \\
\hline Manufacturing & 7,729 & 95.04 & $47.3 \%$ \\
\hline Real estate & 379 & 48.98 & $24.3 \%$ \\
\hline Construction & 869 & 10.60 & $5.2 \%$ \\
\hline Accommodation \& Food services & 323 & 10.51 & $5.2 \%$ \\
\hline Electricity, gas, stream and air conditioner & 75 & 7.40 & $3.7 \%$ \\
\hline supply & & & $2.8 \%$ \\
\hline Information Technology & 745 & 5.71 & $1.8 \%$ \\
\hline Arts, entertainment and recreation & 132 & 3.60 & $1.7 \%$ \\
\hline Transportation and Storage & 322 & 3.43 & $1.6 \%$ \\
\hline Agriculture, forestry and fishing & 500 & 3.24 & $1.5 \%$ \\
\hline Mining and quarrying & 72 & 3.04 & $4.5 \%$ \\
\hline Others (sectors) & 2,442 & 9.21 & \\
\hline
\end{tabular}




\section{MInstitute Macrothink $_{\text {Int }}$}

Source: FIA Vietnam, 2011

\section{FDI Outflows}

In recent years, a remarkable trend has emerged in the FDI outflows including among the ASEAN countries. Data in Table 8 represents the trend of FDI outflows in Vietnam and other ASEAN countries namely Indonesia, Malaysia, the Philippines, Thailand, and Singapore.

Table 8. FDI outflows from World, Vietnam and selected ASEAN countries, 2001-2011\$ Million)

\begin{tabular}{|c|c|c|c|c|c|c|c|c|c|c|c|}
\hline Country & 2001 & 2002 & 2003 & 2004 & 2005 & 2006 & 2007 & 2008 & 2009 & 2010 & 2011 \\
\hline World & $847,918.9$ & $528,136.9$ & 562,585 & 920,612 & 880,031 & $1,311,273$ & $1,994,453$ & $1,969,236.4$ & $1,175,023.3$ & $1,451,222.1$ & $1,694,518.9$ \\
\hline ASEAN & $20,749.8$ & $2,118.3$ & 5,286 & 16,983 & 13,789 & 22,231 & 33,466 & $32,254.5$ & $32,997.3$ & $44,170.8$ & $59,889.8$ \\
\hline Indonesia & 125 & 181.8 & 213 & 3,413 & 3,065 & 2,703 & 4,790 & $5,900.0$ & $2,249.0$ & $2,664.2$ & $7,771.0$ \\
\hline Malaysia & 266.8 & 1904.7 & 1,370 & 2,061 & 2,971 & 6,041 & 10,989 & $14,964.9$ & $7,784.4$ & $13,328.5$ & $15,257.5$ \\
\hline Philippines & -140 & 65 & 303 & 579 & 189 & 103 & 3,442 & 259 & 359 & 616 & 9.0 \\
\hline Singapore & 20,027 & -250 & 2,695 & 10,803 & 6,943 & 12,241 & 12,300 & $6,812.2$ & $17,703.7$ & $21,214.9$ & $25,227.5$ \\
\hline Thailand & 427.4 & 170.6 & 621 & 76 & 503 & 1,032 & 1,756 & $4,056.6$ & $4,172.1$ & $5,414.9$ & $10,634.2$ \\
\hline Viet Nam & - & - & - & - & 65 & 85 & 150 & 300 & 700 & 900 & 950 \\
\hline
\end{tabular}

Source: UNCTAD, World Investment Report, 2011

One may observe that comparatively, Viet Nam has a very poor score in term of FDI outflows. This is obvious since Viet Nam is just coming up as an emerging growing economy in the ASEAN race. It is remarkable that during the period 2001-2011 Singapore ranks first in terms of the amount of FDI outflows to the world economy, and next comes Malaysia but far less.

\section{Transnationality Index}

The concept of Transnationality index has been used by The UNCTAD to indicate the

Proportion of the FDI as component of the total GDP of the country.

Transnationality index of a country (TNIC) is measured by the formula.

$T N I C=\frac{F D I S t o c k}{G D P} \%$

Data in Table 9 represents the Transnationality Index of Vietnam and other ASEAN countries for the period 2001-2011. It is worth mentioning that in case of Vietnam the FDI inflows constitute more than half of the total GDP of the country over the period 2001-2011, this explains the recent growth of the Vietnamese economy which is mainly attributed to the FDI inflows. 


\section{Macrothink}

Business and Economic Research

ISSN 2162-4860

2012, Vol. 2, No. 2

Table 9. The Transnationality Index of Vietnam and other Asian selected countries 2001-2011

\begin{tabular}{|c|c|c|c|c|c|c|c|c|c|c|c|c|}
\hline Country/ Year & & 2001 & 2002 & 2003 & 2004 & 2005 & 2006 & 2007 & 2008 & 2009 & 2010 & 2011 \\
\hline \multirow{3}{*}{ Indonesia } & FDI Stock & 15203.3 & 7116.8 & 10324.3 & 15882.2 & 41551.4 & 52007.1 & 79927.0 & 72227.0 & 108795.0 & 154158.0 & 173064.0 \\
\hline & GDP & 160446.9 & 195537.9 & 234772.5 & 256836.9 & 285868.7 & 364570.4 & 432044.8 & 510829.8 & 538652.7 & 708303.0 & 846208.6 \\
\hline & TNIC & $9.5 \%$ & $3.6 \%$ & $4.4 \%$ & $6.2 \%$ & $14.5 \%$ & $14.3 \%$ & $18.5 \%$ & $14.1 \%$ & $20.2 \%$ & $21.8 \%$ & $20.5 \%$ \\
\hline \multirow{3}{*}{ Malaysia } & FDI Stock & 33971.8 & 37542.4 & 41187.9 & 43046.8 & 44459.5 & 53836.3 & 75762.6 & 73601.3 & 78994.5 & 101510.2 & 114554.6 \\
\hline & GDP & 92783.9 & 100845.5 & 110201.8 & 124749.7 & 137954.2 & 156409.4 & 186719.7 & 222727.9 & 192916.1 & 237805.2 & 278657.7 \\
\hline & TNIC & $36.6 \%$ & $37.2 \%$ & $37.4 \%$ & $34.5 \%$ & $32.2 \%$ & $34.4 \%$ & $40.6 \%$ & $33.0 \%$ & $40.9 \%$ & $42.7 \%$ & $41.1 \%$ \\
\hline \multirow{3}{*}{ Philippines } & FDI Stock & 10385.0 & 11565.0 & 11411.0 & 12745.0 & 14562.0 & 16024.0 & 20463.0 & 21746.0 & 22931.0 & 26319.0 & 27581.0 \\
\hline & GDP & 76262.0 & 81357.7 & 79633.6 & 86930.1 & 98828.9 & 117566.3 & 144062.3 & 174195.1 & 168334.5 & 199590.8 & 224753.7 \\
\hline & TNIC & $13.6 \%$ & $14.2 \%$ & $14.3 \%$ & $14.7 \%$ & $14.7 \%$ & $13.6 \%$ & $14.2 \%$ & $12.5 \%$ & $13.6 \%$ & $13.2 \%$ & $12.3 \%$ \\
\hline \multirow{3}{*}{ Thailand } & FDI Stock & 33267.0 & 38449.0 & 48944.0 & 53187.0 & 60408.0 & 76174.0 & 94112.2 & 93499.9 & 106154.1 & 137191.2 & 139734.6 \\
\hline & GDP & 115418.0 & 126716.0 & 142640.1 & 161339.9 & 176419.7 & 206703.2 & 245350.6 & 272156.9 & 263367.7 & 318473.5 & 345670.3 \\
\hline & TNIC & $28.8 \%$ & $30.3 \%$ & $34.3 \%$ & $33.0 \%$ & $34.2 \%$ & $36.9 \%$ & $38.4 \%$ & $34.4 \%$ & $40.3 \%$ & $43.1 \%$ & $40.4 \%$ \\
\hline \multirow{3}{*}{ Viet Nam } & FDI Stock & 23021.6 & 26055.2 & 27505.2 & 29115.3 & 31136.3 & 33496.4 & 40169.2 & 49748.2 & 57348.2 & 65348.2 & 72778.2 \\
\hline & GDP & 32685.2 & 35064.1 & 39552.5 & 45427.9 & 52917.4 & 60913.3 & 71076.7 & 89185.2 & 80901.2 & 96634.7 & 123664.9 \\
\hline & TNIC & $70.4 \%$ & $74.3 \%$ & $69.5 \%$ & $64.1 \%$ & $58.8 \%$ & $55.0 \%$ & $56.5 \%$ & $55.8 \%$ & $70.9 \%$ & $67.6 \%$ & $58.9 \%$ \\
\hline
\end{tabular}

\section{Competitiveness in FDI}

UNCTAD has provided empirical measures to perceive a country's competitiveness in the FDI inflows and outflows. These are referred to as an inwards performance index and an outward FDI performance index and their potential to attract FDI flows.

\subsection{Inward FDI Performance Index (IFPI)}

IFPI is measured using the ratio of a country's share in global FDI inflows to its share in global GDP, expressed in terms of 100. Thus:

$I F P I x=\frac{F D L x / W F D I}{G D P x / W G D P} \%$

Where,

IFPIx = The inwards FDI Performance Index of the Country $\mathrm{X}$

FDIx = The FDI inflows in the country $\mathrm{X}$

WFDI $=$ World FDI inflows

GDPx = Gross Domestic Product of country X

$\boldsymbol{W G D P}=$ World Gross Domestic Product

The IFPI is used to determine the ranks of countries in attracting FDI. The IFPI indicates a country's propensity to attract FDI after adjusting for its relative economic size and strength such as international exposure or position in the global arena. It is a measure useful to the policy makers to compare how well their country performs in attracting FDI relative to others. 


\section{Ml Macrothink}

Business and Economic Research

ISSN 2162-4860

2012, Vol. 2, No. 2

The index captures the implicit influence on FDI of factors other than market size such as business climate, economic and political stability, and environments of natural and acquired resources, skills and technology advancement, and the effectiveness of FDI promotion (WIR, 2006). Data in Table 10 refers to the IFPI of Vietnam and other ASEAN countries for the period 2001-2011.The data shows that

Viet Nam has the highest IFPI index among other ASEAN countries during the period 2001-2011.

Table 10: The IFPI measure of Vietnam and Asian selected countries over the period 2001-2011

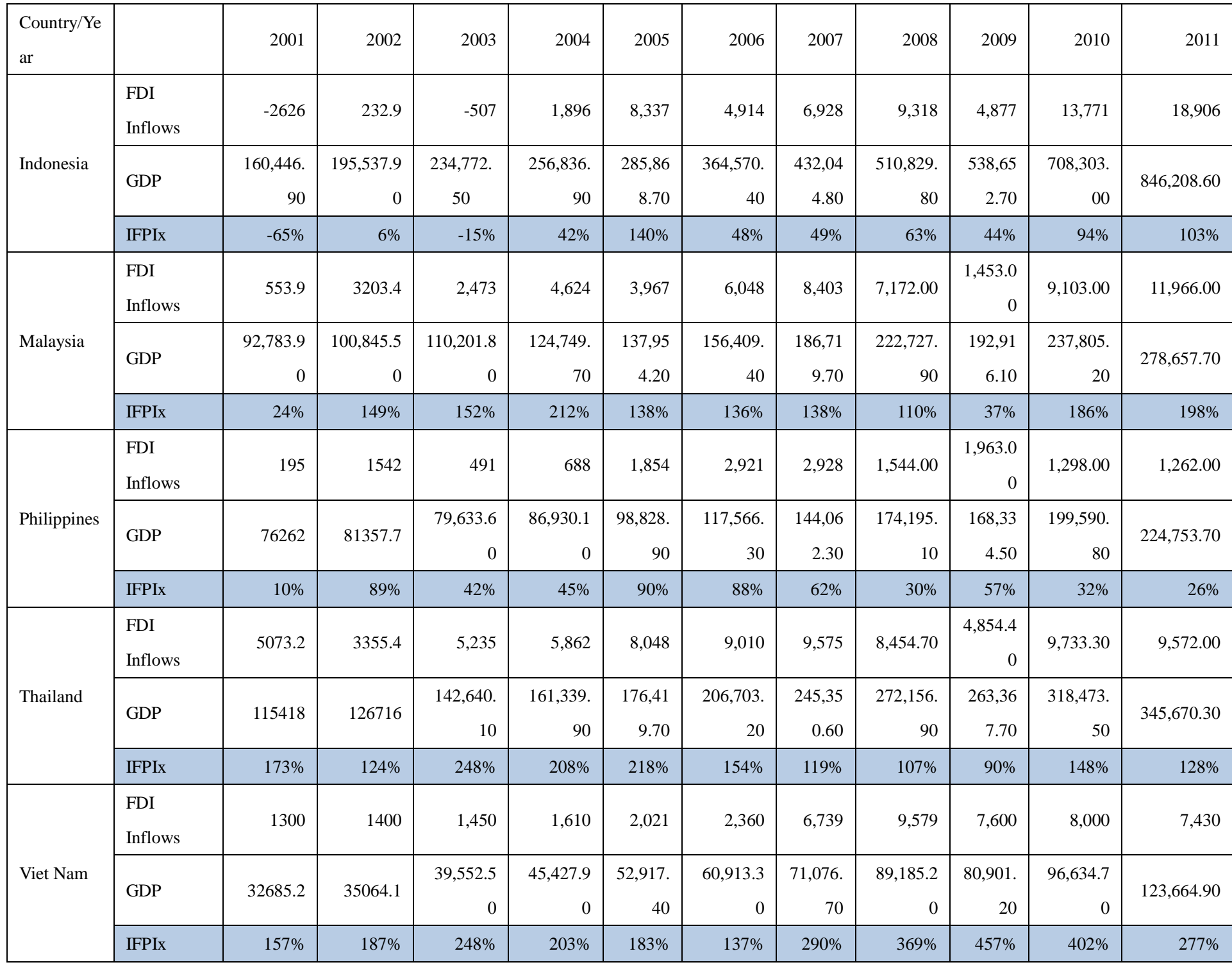

The data reveal that Indonesia received increasing flows with quantum jump during 2010 and 2011.Phillpine also stood secured to Indonesia in receiving high flows during 2011. Malaysia stood the next against this ASEASE Viet Nam trend, however, empirical declining flow in 2011. 


\section{Macrothink}

Business and Economic Research

ISSN 2162-4860

2012, Vol. 2, No. 2

\subsection{The Outward FDI Performance Index (OFPI)}

The Outward FDO Performance Index (OFPI) is measured as the share of a country's outward FDI in global FDI outflow as a ratio of its share in the world GDP. It is worked out as follows:

$O F P L x=\frac{F D I O x / W F D I O}{G D P x / W G D P} \%$

Where,

OFPIx = The outwards FDI Performance Index of the Country $\mathrm{X}$

FDIOx $=$ The FDI outflows in the country $\mathrm{X}$

WFDIO $=$ World FDI outflows

GDPx = Gross Domestic Product of country X

$W G D P=$ World Gross Domestic Product

Using this formula, OFPI is estimated for Viet Nam and other ASEAN countries as in Table 11.

It follows that Malaysia ranks at the top, while Viet Nam at the bottom amongst the Compared countries in the matter of FDI outflows.

\section{Business Environment Indicator}

A conducive environment for doing business is necessary for attracting the FDI inflows in the country. Data in Table 12 help in perceiving the ease of doing business in selected ASEAN countries.

Table 11. The Outward FDI performance of Viet Nam and other Asian countries 2001-2011

\begin{tabular}{|c|c|c|c|c|c|c|c|c|c|c|c|c|}
\hline $\begin{array}{l}\text { Country/ } \\
\text { Year }\end{array}$ & & 2001 & 2002 & 2003 & 2004 & 2005 & 2006 & 2007 & 2008 & 2009 & 2010 & 2011 \\
\hline \multirow{3}{*}{ Indonesia } & $\begin{array}{l}\text { FDI } \\
\text { Outflows }\end{array}$ & 125 & 181.8 & 213 & 3,413 & 3,065 & 2,703 & 4,790 & 5,900 & 2,249 & 2,664 & 7,771 \\
\hline & GDP & $\begin{array}{c}160,446 \\
90\end{array}$ & $\begin{array}{c}195,537.9 \\
0\end{array}$ & $\begin{array}{c}234,772 . \\
50\end{array}$ & $\begin{array}{c}256,83 \\
6.90\end{array}$ & $\begin{array}{c}285,868 \\
.70\end{array}$ & $\begin{array}{c}364,570 . \\
40\end{array}$ & $432,044.80$ & $510,829.80$ & $538,652.70$ & $708,303.00$ & $846,208.60$ \\
\hline & OFPIx & $3 \%$ & $6 \%$ & $6 \%$ & $61 \%$ & $56 \%$ & $28 \%$ & $31 \%$ & $36 \%$ & $21 \%$ & $16 \%$ & $38 \%$ \\
\hline \multirow{3}{*}{ Malaysia } & $\begin{array}{l}\text { FDI } \\
\text { Outflows }\end{array}$ & 266.8 & 1904.7 & 1,370 & 2,061 & 2,971 & 6,041 & 10,989 & $14,964.90$ & $7,784.40$ & $13,328.50$ & $15,257.50$ \\
\hline & GDP & $\begin{array}{c}92,783.9 \\
0\end{array}$ & $\begin{array}{c}100,845.5 \\
0\end{array}$ & $\begin{array}{c}110,201 \\
80\end{array}$ & $\begin{array}{c}124,74 \\
9.70\end{array}$ & $\begin{array}{c}137,954 \\
.20\end{array}$ & $\begin{array}{c}156,409 . \\
40\end{array}$ & $186,719.70$ & $222,727.90$ & $192,916.10$ & $237,805.20$ & $278,657.70$ \\
\hline & OFPIx & $11 \%$ & $120 \%$ & $83 \%$ & $76 \%$ & $112 \%$ & $147 \%$ & $165 \%$ & $210 \%$ & $200 \%$ & $246 \%$ & $227 \%$ \\
\hline \multirow{3}{*}{ Philippines } & $\begin{array}{l}\text { FDI } \\
\text { Outflows }\end{array}$ & -140 & 65 & 303 & 579 & 189 & 103 & 3,442 & 259.00 & 359.00 & 616.00 & 9.00 \\
\hline & GDP & 76262 & 81357.7 & $\begin{array}{c}79,633.6 \\
0\end{array}$ & $\begin{array}{c}86,930 . \\
10\end{array}$ & $\begin{array}{c}98,828 . \\
90\end{array}$ & $\begin{array}{c}117,566 \\
30\end{array}$ & $144,062.30$ & $174,195.10$ & $168,334.50$ & $199,590.80$ & $224,753.70$ \\
\hline & OFPIx & $-7 \%$ & $5 \%$ & $25 \%$ & $31 \%$ & $10 \%$ & $3 \%$ & $67 \%$ & $5 \%$ & $11 \%$ & $14 \%$ & $0 \%$ \\
\hline
\end{tabular}




\section{Al Macrothink}

Business and Economic Research

ISSN 2162-4860

2012, Vol. 2, No. 2

\begin{tabular}{|c|c|c|c|c|c|c|c|c|c|c|c|c|}
\hline \multirow{3}{*}{ Thailand } & $\begin{array}{l}\text { FDI } \\
\text { Outflows }\end{array}$ & 427.4 & 170.6 & 621 & 76 & 503 & 1,032 & 1,756 & $4,056.60$ & $4,172.10$ & $5,414.90$ & $10,634.20$ \\
\hline & GDP & 115418 & 126716 & $\begin{array}{c}142,64 \\
0.10\end{array}$ & $\begin{array}{c}161,33 \\
9.90\end{array}$ & $\begin{array}{c}176,41 \\
9.70\end{array}$ & $\begin{array}{c}206,70 \\
3.20\end{array}$ & $\begin{array}{c}245,350 . \\
60\end{array}$ & $\begin{array}{c}272,156.9 \\
0\end{array}$ & $263,367.70$ & $318,473.50$ & $345,670.30$ \\
\hline & OFPIx & $14 \%$ & $9 \%$ & $29 \%$ & $2 \%$ & $15 \%$ & $19 \%$ & $20 \%$ & $47 \%$ & $79 \%$ & $74 \%$ & $128 \%$ \\
\hline \multirow{3}{*}{ Viet Nam } & $\begin{array}{l}\text { FDI } \\
\text { Outflows }\end{array}$ & - & - & - & - & 65 & 85 & 150 & 300 & 700 & 900 & 950 \\
\hline & GDP & 32685.2 & 35064.1 & $\begin{array}{c}39,552 . \\
50\end{array}$ & $\begin{array}{c}45,427 \\
.90\end{array}$ & $\begin{array}{c}52,917 \\
.40\end{array}$ & $\begin{array}{c}60,913 . \\
30\end{array}$ & $\begin{array}{c}71,076.7 \\
0\end{array}$ & $89,185.20$ & $80,901.20$ & $96,634.70$ & $123,664.90$ \\
\hline & OFPIx & - & - & - & - & $6 \%$ & $5 \%$ & $6 \%$ & $10 \%$ & $43 \%$ & $41 \%$ & $32 \%$ \\
\hline
\end{tabular}

Table 12. Ease of Doing Business Indices in Selected ASEAN Countries, 2011

\begin{tabular}{|c|c|c|c|c|c|c|c|c|c|c|c|}
\hline Economy & $\begin{array}{c}\text { Ease of } \\
\text { Doing } \\
\text { Business } \\
\text { Rank }\end{array}$ & $\begin{array}{c}\text { Starting } \\
\text { a } \\
\text { Business }\end{array}$ & $\begin{array}{c}\text { Dealing } \\
\text { with } \\
\text { Construction } \\
\text { Permits }\end{array}$ & $\begin{array}{c}\text { Employing } \\
\text { Workers }\end{array}$ & $\begin{array}{c}\text { Registering } \\
\text { Property }\end{array}$ & $\begin{array}{c}\text { Getting } \\
\text { Credit }\end{array}$ & $\begin{array}{c}\text { Protecting } \\
\text { Investors }\end{array}$ & $\begin{array}{c}\text { Paying } \\
\text { Taxes }\end{array}$ & $\begin{array}{c}\text { Trading } \\
\text { Across } \\
\text { Borders }\end{array}$ & $\begin{array}{l}\text { Enforcing } \\
\text { Contracts }\end{array}$ & $\begin{array}{c}\text { Closing } \\
\text { a } \\
\text { Business }\end{array}$ \\
\hline Singapore & 1 & 4 & 3 & 5 & 14 & 8 & 2 & 4 & 1 & 12 & 2 \\
\hline $\begin{array}{l}\text { United } \\
\text { States }\end{array}$ & 3 & 13 & 17 & 17 & 16 & 4 & 5 & 72 & 20 & 7 & 15 \\
\hline $\begin{array}{c}\text { United } \\
\text { Kingdom }\end{array}$ & 7 & 19 & 22 & 60 & 68 & 1 & 10 & 24 & 13 & 21 & 6 \\
\hline Japan & 20 & 107 & 63 & 26 & 58 & 24 & 17 & 120 & 16 & 34 & 1 \\
\hline Thailand & 17 & 78 & 14 & 9 & 28 & 67 & 13 & 100 & 17 & 24 & 51 \\
\hline Malaysia & 18 & 50 & 113 & 59 & 59 & 1 & 4 & 41 & 29 & 31 & 47 \\
\hline Pakistan & 105 & 90 & 104 & 166 & 125 & 67 & 29 & 158 & 75 & 154 & 74 \\
\hline China & 91 & 151 & 179 & 115 & 40 & 67 & 97 & 122 & 60 & 16 & 75 \\
\hline Brunei & 83 & 136 & 83 & 28 & 107 & 126 & 122 & 20 & 35 & 151 & 44 \\
\hline Vietnam & 98 & 103 & 67 & 135 & 47 & 24 & 166 & 151 & 68 & 30 & 142 \\
\hline India & 132 & 166 & 181 & 98 & 97 & 40 & 46 & 147 & 109 & 182 & 128 \\
\hline Indonesia & 129 & 155 & 71 & 161 & 99 & 126 & 46 & 131 & 39 & 156 & 146 \\
\hline Cambodia & 138 & 171 & 149 & 130 & 110 & 98 & 79 & 54 & 120 & 142 & 149 \\
\hline Lao PDR & 165 & 89 & 80 & 138 & 72 & 166 & 182 & 123 & 168 & 110 & 183 \\
\hline
\end{tabular}

Source: World Bank Report 2011

Based on the Table 13, Thailand is ranked 17 as per the indices for the ease of doing business. The time taken to register the property is only 2 days in Thailand. Malaysia is ranked 25 for the ease of doing business, but the time takes to register the property is 144 days compared to Indonesia (42 days) and Philippines (33 days). It means that Malaysia is more bureaucratic 
among the ASEAN-4 countries. India too is equally bureaucratic amongst the Asian nations.

Viet Nam's rank is much lower in terms of these business indices. Still, she has a better rank (98) in comparison to India(132), Indonesia (129), and the Philippines (136).

Data in Table 13 relates to economic freedom indices for Viet Nam and other ASEAN countries.

Table 16. Economic Freedom in Viet Nam and other ASEAN countries, 2011

\begin{tabular}{|c|c|c|c|c|c|c|c|c|c|c|c|}
\hline Country & $\begin{array}{c}2011 \\
\text { Average }\end{array}$ & $\begin{array}{l}\text { Business } \\
\text { Freedom }\end{array}$ & $\begin{array}{c}\text { Trade } \\
\text { Freedom }\end{array}$ & $\begin{array}{c}\text { Fiscal } \\
\text { Freedom }\end{array}$ & $\begin{array}{l}\text { Gov't } \\
\text { Size }\end{array}$ & $\begin{array}{l}\text { Monetary } \\
\text { Freedom }\end{array}$ & $\begin{array}{l}\text { Investment } \\
\text { Freedom }\end{array}$ & $\begin{array}{l}\text { Financial } \\
\text { Freedom }\end{array}$ & $\begin{array}{l}\text { Property } \\
\text { Rights }\end{array}$ & $\begin{array}{c}\text { Freedom } \\
\text { from } \\
\text { Corruption }\end{array}$ & $\begin{array}{c}\text { Labor } \\
\text { Freedom }\end{array}$ \\
\hline Indonesia & 56.0 & 54.9 & 73.8 & 83.0 & 88.9 & 74.3 & 35.0 & 40.0 & 30.0 & 28.0 & 51.8 \\
\hline Malaysia & 66.3 & 69.7 & 78.7 & 84.6 & 79.2 & 81.3 & 45.0 & 50.0 & 50.0 & 45.0 & 79.2 \\
\hline Philippines & 56.2 & 43.4 & 77.8 & 78.8 & 91.0 & 76.3 & 40.0 & 50.0 & 30.0 & 24.0 & 50. \\
\hline Singapore & 87.2 & 98.2 & 90.0 & 91.1 & 91.3 & 86.2 & 75.0 & 60.0 & 90.0 & 92.0 & 98.0 \\
\hline Thailand & 87.2 & 98.2 & 90.0 & 91.1 & 91.3 & 86.2 & 75.0 & 60.0 & 90.0 & 92.0 & 98.0 \\
\hline Vietnam & 51.6 & 61.6 & 68.9 & 75.9 & 75.1 & 79.1 & 15.0 & 30.0 & 15.0 & 27.0 & 68.2 \\
\hline
\end{tabular}

Source: Kim R. Holmes. Edwin J. Feulner and Mary Anastasia O'Grady, 2011 Index of Economic Freedom at www.heritage.org/index

Overall economic freedom index of Singapore (87.1) is the highest among other countries. Malaysia stands the next with the score of 64.6, whereas Viet Nam stands last with its score 51.0. Singapore business freedom index very high at 98.3 , next is Thailand at 71.1 followed by Malaysia with a score of 70.8. Viet Nam's score is 76.7 which is much better than that of Malaysia and Philippines.

Singapore is the least corrupted country in the ASEAN region. Her Freedom from Corruption Index (FCI) is remarkably high at 93.0. Malaysia's score (50) on freedom from corruption which is half of that of Singapore. Viet Nam has a poor score (26.0) implying a high degree of corruption. Viet Nam in the ASEAN cluster should improve its checks, detection and regulatory power in business friendly ways and make the nations free from corruption. Under the powers of bureaucracies should be simple, few and devoid of loopholes.

Data in Table 14 refers to the Enabling Trade Index (FTI) reported in the Global Enabling Trade Report (2008) by the World Economic Forum.

Table 14. The Enabling Trade Index 2011

\begin{tabular}{|c|c|c|c|c|c|c|c|c|c|c|}
\hline \multirow{3}{*}{ Country/Economy } & \multicolumn{10}{|c|}{ SUBINDEXES } \\
\hline & \multicolumn{2}{|c|}{$\begin{array}{l}\text { OVERALL } \\
\text { INDEX }\end{array}$} & \multicolumn{2}{|c|}{$\begin{array}{l}\text { Market } \\
\text { Access }\end{array}$} & \multicolumn{2}{|c|}{$\begin{array}{c}\text { Border } \\
\text { Administration }\end{array}$} & \multicolumn{2}{|c|}{$\begin{array}{c}\text { Transport \& } \\
\text { communication } \\
\text { infrastructure }\end{array}$} & \multicolumn{2}{|c|}{$\begin{array}{c}\text { Business } \\
\text { Environment }\end{array}$} \\
\hline & Rank & Score & Rank & Score & Rank & Score & Rank & Score & Rank & Score \\
\hline Singapore & 1 & 6.14 & 1 & 6.20 & 1 & 6.53 & 1 & 6.06 & 5 & 5.75 \\
\hline Malaysia & 24 & 4.90 & 39 & 4.68 & 24 & 5.23 & 30 & 5.25 & 30 & 5.03 \\
\hline
\end{tabular}




\begin{tabular}{|c|c|c|c|c|c|c|c|c|c|c|}
\hline Indonesia & 58 & 4.19 & 17 & 4.86 & 65 & 4.06 & 86 & 3.03 & 110 & 9.90 \\
\hline China & 56 & 4.22 & 108 & 3.55 & 45 & 4.42 & 48 & 4.27 & 45 & 4.63 \\
\hline Thailand & 57 & 4.21 & 59 & 4.03 & 47 & 4.41 & 46 & 4.30 & 76 & 4.13 \\
\hline Sri Lanka & 73 & 3.95 & 103 & 3.89 & 73 & 3.89 & 81 & 3.65 & 47 & 4.59 \\
\hline India & 100 & 3.55 & 130 & 2.60 & 84 & 2.99 & 22 & 41.52 & 74 & 4.20 \\
\hline Philippines & 72 & 3.96 & 14 & 4.90 & 72 & 3.90 & 91 & 3.41 & 107 & 3.61 \\
\hline Pakistan & 116 & 3.39 & 128 & 2.95 & 71 & 3.92 & 95 & 3.35 & 123 & 3.34 \\
\hline Viet Nam & 68 & 4.02 & 41 & 4.37 & 94 & 3.45 & 56 & 4.04 & 69 & 4.24 \\
\hline
\end{tabular}

Source: World Economic Forum: Global Enabling Trade Report (2011)

Among the 118 countries of the world, as per the ETI, Singapore ranks $1^{\text {st }}$ Malaysia is ranked as the $29^{\text {th }}$, Indonesia is ranked as the $58^{\text {th }}$, Thailand is the 52th, the Philippines is the 82th , and lastly comes Viet Nam as the $91^{\text {st }}$. In other Indices, such as market access, border administration, infrastructure and business environment, Viet Nam still commanding on rank perception as per the Index Value (68) in 2011 and needs policy makers due attention substantial for improvement.

\section{Global Competitive Index 2008-2011}

The World Economic Forum produced in cooperation with global academic institutes of research has coined the Global Competitiveness Index which is a comprehensive assessment of countries' competitiveness. Its data in Table 15 depict a current scenario for the selected countries. Vietnam has come down by 2 levels since last year and its competitive index is low comparing to ASEAN-4, China, and India.

Table 15. Rank of Countries' Competitiveness

\begin{tabular}{|l|c|c|c|c|}
\hline Country & Rank 2008 & Rank 2009 & Rank 2010 & Rank 2011 \\
\hline China & 30 & 26 & 27 & 26 \\
\hline India & 50 & 52 & 51 & 56 \\
\hline Indonesia & 55 & 56 & 44 & 46 \\
\hline Malaysia & 21 & 21 & 26 & 21 \\
\hline Singapore & 5 & 3 & 3 & 2 \\
\hline Thailand & 34 & 40 & 38 & 39 \\
\hline Viet Nam & 70 & 72 & 59 & 65 \\
\hline
\end{tabular}

Source: World Economic Forum, 2011

It is heartening to not that Viet Nam rank in degree of comparative has improved during recent years from 70 in 2008 to 65 in 2011.

\section{Suggested Course of Policy Directions to Promote FDI in Viet Nam}

There can be several modes of policies to promote FDI in a country. The most common policy incentives are partial or complete exemptions from corporate taxes and import duties. Among other incentives there are the establishment of the special economic zone (SEZs), tax holidays, import duty exemptions, and different kinds of direct subsidies. FDI inflows are also affected by corporate tax rate differentiation. There has been an ongoing trend to lower corporate income taxes in the developing countries like ASEAN 4. Moreover, subsidizing FDI helps multinational firms to reduce production costs, to create patents, trademarks, and enhances the relative attractiveness of locating production facilities in the country. The policy makers in Viet 
Nam have to study them and make the necessary measures to come up with the most appropriate plan with which the country can be a hard competitive nation. The country such as Viet Nam should evolve a mix of outward and inward looking growth strategy. The policy makers in Viet Nam can exploit the situation of growing opportunities as suppliers of several products and technology through domestic output as well as outsourcing. The country such as Malaysia should be invited for the outflow of its direct investment in Vietnam.

Along with the ASEAN-4 countries, Viet Nam needs to evolve new paradigms (such as six-sigma system, IS 14,000, total ICT-orientation as norms-improvement system) as productivity and quality will be the hallmarks in gaining strong foothold and seizing the emerging opportunities in the regional pockets of the global economy. Serious efforts are required on productivity aspects and quality improvement and competitive pricing for an increased level of Viet Nam's exports in the years to follow. It is possible with integration, dedication and techno-economic cooperation of the ASEAN and Asian nations. Viet Nam should try to improve her trade and investment relations with India, and prove that distance does not matter in global economic integration.

By and large; Viet Nam's future depends on mitigating threats and converting the opportunities in building its strength, overcoming weakness through implementation of various strategies and initiatives at the local, national, regional and multilateral levels. There is also a need to revitalize and redesign management practices by evolving a Viet Nam-centric, Vietnams' style of management to motivate the Vietnams' workers towards both 'hard-work' and 'smart-work' with greater devotion and sincerity for the betterment of self and society together. Imperatively, being a developing cluster in the global setting. Viet Nam should seek to join the ASEAN-4 cluster. The new cluster has to maintain a stable, balanced macroeconomic environment through a 'mix' of prudent monetary exchange rate and fiscal and trade policies contributing to its export-led growth strategy centered around the attraction of foreign direct investment with due diversification and to further reform and development of its banking and financial system. Viet Nam should tighten its linkages with China, Japan, ASEAN, USA, and with the European Nation as well as India, Sri Lanka, Africa, Iran and Iraq in the making in due course of time. The country can certainly gain trough 'Give and Take' Policy with the emerging markets of Asia and Africa.

This paper examined the business and economic scenario of foreign direct investment (FDI) in Viet Nam in comparison to the ASEAN-4 in the region, following the review of growth trend of FDI during 2001 to 2011. The flows of FDI can contribute substantially to the ASEAN's newly emerging economic cluster comparing Vietnam, Cambodia and Laos as promising neighboring of fast moving Thailand. An interaction of VCLT (Viet Nam, Cambodia, Laos and Thailand) is suggested on the pattern of IMT-GT for policy makers to think under within a short span of time.

The Decision makers in Viet Nam should promote FDI in new areas of the economy, in particular, the service sectors. Further, Viet Nam should adopt a flexible regulation system and reduce the administrative burden. The country's plan for development should take into consideration the importance of improving the qualities of the infrastructure and enhancing the 
worker productivity through continuous technical and managerial training. The government of Viet Nam should treat equally the state owned enterprises and private companies in order for the whole economic environment to be appealing and attractive. The Vietnamese government should remain committed to its attributes of monetary and fiscal discipline essential towards macro balancing.

By and large, positive action should be taken to improve the Vietnam's eco- political risk rating to make it more attractive to foreign investors. This includes a wide range of policy options such as a reduction in crime, good governance and continued macroeconomic stability. The policy-makers should encourage foreign -owned firms (FOFs) to use locally produced inputs/materials afar as possible. Tax incentives may be given for using domestic inputs. Secondly export- led growth strategy of the country has shown positive results; therefore, activity of export-oriented FOFs should be encouraged. Furthermore, for the transformation of the Vietnam's K-economy it is essential that FOFs should be encouraged to participate in high-tech industries. The government should continue to follow its first wisdom and increase the share of expenditure on education and labor training program with a focus on human knowledge development in the countries.

The policy makers in Viet Nam should realize that there is an urgent need to device promotional actions for investment awareness and program rather than just indicating gross incentives. A detailed indicative planning for the FDI flows is required Viet Nam. Small and medium enterprises (SMES) may be assigned a specified role in the global business opportunities by facilitating them with hardware, software and analytical tools for their effective participation in implementing under the foreign direct investment promotion program and planning. Considering the business environment issues, the government should improve the legal system and environment to attract more FDI inflows, and the legal system should be always reviewed and improved. Moreover, the regulations, laws of FDI should be made transparent; this will make it very much attractive environment to all global investors. Above all, the government should do all the possible efforts to maintain a stable economic growth rate and improve other indicators of the economic environment such as controllable inflation, and appropriate exchange rate.

\section{Conclusion}

Viet Nam Policy Makers should recognize the virtuous circle between FDI - human capital economic growth. They need to assess "Time to time" the country's level of human capital and its potential to attract the FDI inflow. Policies should focus on term of agreements and the pattern of FDI inflows that should lead to the transfer of technology and managerial skills with technical know-how for the country's benefit. Viet Nam policy makers should see that MNCs should contribute towards education and training centers in the country. Efforts must be made to bridge the technology gap between local and foreign enterprises in the country.

\section{References}

Ball, D. A., McCulloch, W. H., Frantz, P. L., Geringer, J. M. \& Minor, M. S. (2004). International Business the challenge of global competition, McGraw Hill, New York. 


\section{Macrothink}

Business and Economic Research ISSN 2162-4860 2012, Vol. 2, No. 2

Campos, F. N. \& Kinoshita Y. (2003).Why does FDI go where it goes? New Evidence from the Transition Economies. IMF Working Paper No. 228.

Casson, M. (1990). "The Theory of Foreign Direct Investment", in Buckley P. (ed.), International Investment, Aldershot: Edward Elgar Publishing.

Caves, R. E. (1974). Multinational Firms, Competition and Productivity in Host-country Markets", Economica, 32, 176-193. http://dx.doi.org/10.2307/2553765

Dunning, J. H. (1993). "Multinational Enterprises and the Global Economy. New York: Addison-Wesley Publishing Company.

Fernandez Leanos (2003). “A Look at Foreign Direct Investment in Malaysia”, Star, January.

Fry, M.J. (1991). "Domestic Resource Mobilization in Developing Asia: Four Policy Issues", Asian Development Review 9, No.1.

Fry, M.J. (1993). Foreign Direct investment in Southeast Asia, Differential Impacts, Sean Institute of Southeast Asia Studies, Singapore.

Haddad, M. \& Harrison. A. (1993). "Are there Positive Spillovers from Direct Foreign Investment?" Journal of Developing Economics, 42, 51-74. http://dx.doi.org/10.1016/0304-3878(93)90072-U

International Monetary Fund (2003). Foreign Direct Investment Trends and Statistics, Washington D.C.

Markusen, J. R. \& Venables, A. J. (1999), Foreign Direct Investment as a Catalyst for Industrial Development. European Economic Review, 43, 335-356. http://dx.doi.org/10.1016/S0014-2921(98)00048-8

Nikomborirah, Deurden (2004). An Assessment of the Investment Regime: Thailand Country Report, Thailand Development Research Institute, Bangkok.

Rudra Prakuh Radhan (2006). FDI in globalization Era: Chinese and Indian Experience, Prajran-Journal of Social and Management Science, vol XXXVV no 4, January - March 2006.

Syed Ahmad, Abdul Hamid Sukar and Saheheen Khan (2005). Determinants of Foreign Direct Investments in ASEAN-4 Countries: Estimation of Panel Data, Federation of Business Discipline (FBD), Annual Meeting, Dallas, March 2005.

The Brooker Group Plc (2002 ). Foreign Direct Investment: Performance and Attraction - The Case of Thailand, presents at the Workshop on Foreign Direct Investment: Opportunity and Challenges for Cambodia, Laos and Vietnam, in Hanoi. August 16-17,2002.

Towney, Michael J. (2000). "A Century of Foreign Investment in the Third World", London, Routledge.

UNCTAD (2011), World Investment Report, New York: UN. 
UNCTAD (2011), World Investment Report, New York: UN.

UNCTAD (2011), World Investment Report, New York: UN.

World Economic Forum (2011). The Global Enabling Trade Report, 2008.

www.aseansec. org.

\section{Copyright Disclaimer}

Copyright reserved by the author(s).

This article is an open-access article distributed under the terms and conditions of the Creative Commons Attribution license (http://creativecommons.org/licenses/by/3.0/). 